\title{
Occupational Health and Safety in Agricultural Production ${ }^{\#}$
}

\author{
Yaşar Serhat Saygılı, 1,a,", Bülent Çakmak ${ }^{2, b}$ \\ ${ }^{1}$ Department of Biosystems Engineering, TBTF, Niğde Ömer Halisdemir University, 51240 Niğde, Turkey \\ ${ }^{2}$ Department of Agricultural Machinery and Technologies Engineering, Faculty of Agriculture, Ege University, 35040 Izmir, Turkey \\ *Corresponding author
}

\section{A R T I C L E I N F O A B S T R A C T}

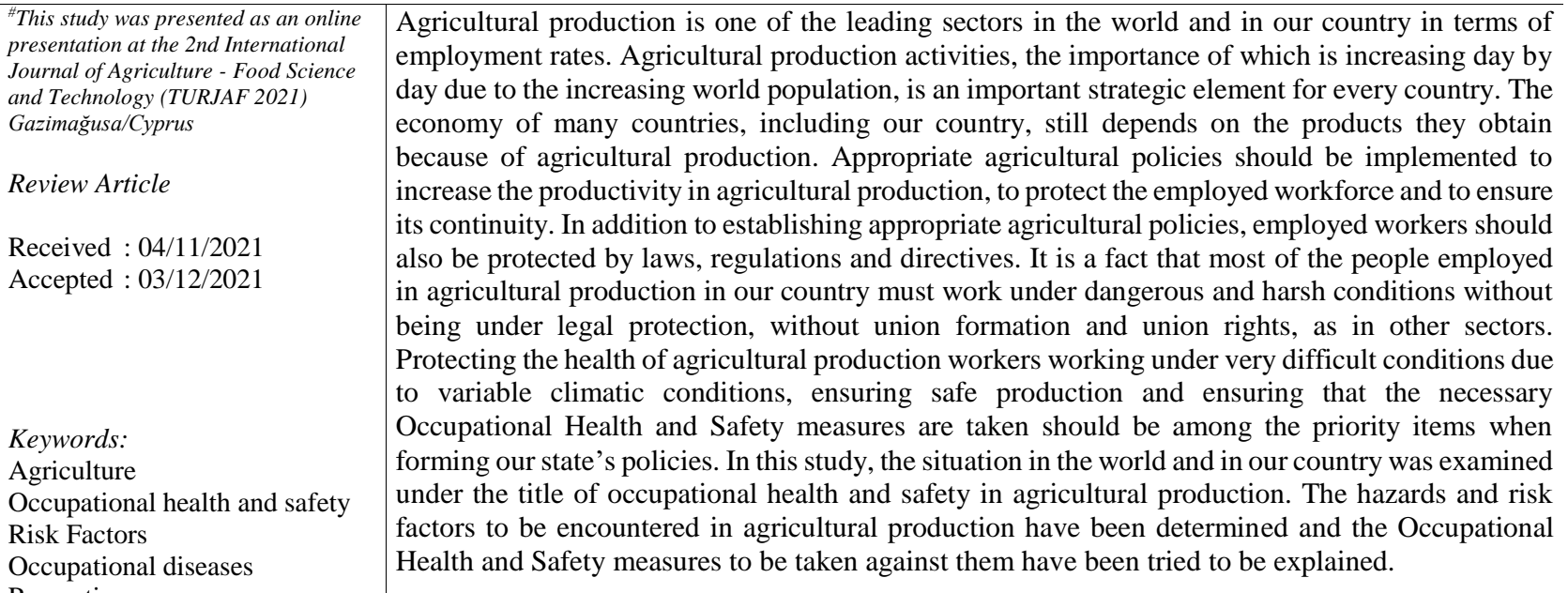

Prevention

\section{Introduction}

Agriculture is a sector that is primarily affected by geographical features and climatic conditions, where different methods, machinery and labor are used to produce a wide variety of plant and animal species in open and closed areas. It is stated that 1.1 billion people are engaged in agriculture in this sector where approximately one third of the world workforce is employed (Anonymous, 2011).

In agricultural production, which is defined in detail in the International Labor Organization (ILO) Convention No. 184 , it is seen that there are many safety risks and health problems that the employed people may encounter because it covers a wide variety of activities. It can be said that people employed in agricultural production are faced with physical, chemical, biological, ergonomic and psychosocial risk factors, considering their environment (Ahioğlu, 2009). Due to the diversity and excess of risk factors, the risk of occupational accidents and occupational diseases for those working in agricultural production is quite high. The level of awareness about risks in agricultural production, where there are many variables such as the number of employees, working hours, qualifications of the employees, the size of the enterprise and the field of activity of the enterprise, significantly affects the practices for the prevention of work accidents and occupational diseases. However, since the level of awareness has not reached a sufficient level both in our country and in the world, many agricultural workers/employees have occupational accidents and/or occupational diseases every year. According to the data of the ILO, approximately 170,000 people die every year because of accidents during agricultural production, and a significant portion of them are injured at the level of incapacity for work or get occupational diseases (Akylddı et al., 2017; Bilir, 2016). 


\section{Workforce in the World and in Turkey}

The segment that the occupational health and safety issue is primarily affected and dealt with is the "Employees". The number of people who are old enough to participate in the workforce (over the age of 15) in the world is estimated to be 5.79 billion. According to the ILO, 3,266 x 109 people were employed in 2018 and 3,304 x 109 people in 2019 (Anonymous, 2021a; Anonymous, $2021 b)$. For $2019,61.14 \%$ of the world's total workforce is men and $38.86 \%$ is women (Anonymous, 2021d). The ILO estimates that around 2.3 million men and women worldwide die each year because of work accidents or occupational diseases. When this figure is calculated on a day basis, it corresponds to 6600 employees. Estimating that there are approximately 340 million occupational accidents and 160 million victims of occupational diseases worldwide, the ILO reports that the numbers of occupational accidents and diseases tend to increase as these numbers are updated (Anonymous, 2021c). In Figure 1 , the changes seen and expected to be seen in the workforce between 1992-2021 on a sectoral basis in the world and in Turkey are shown.

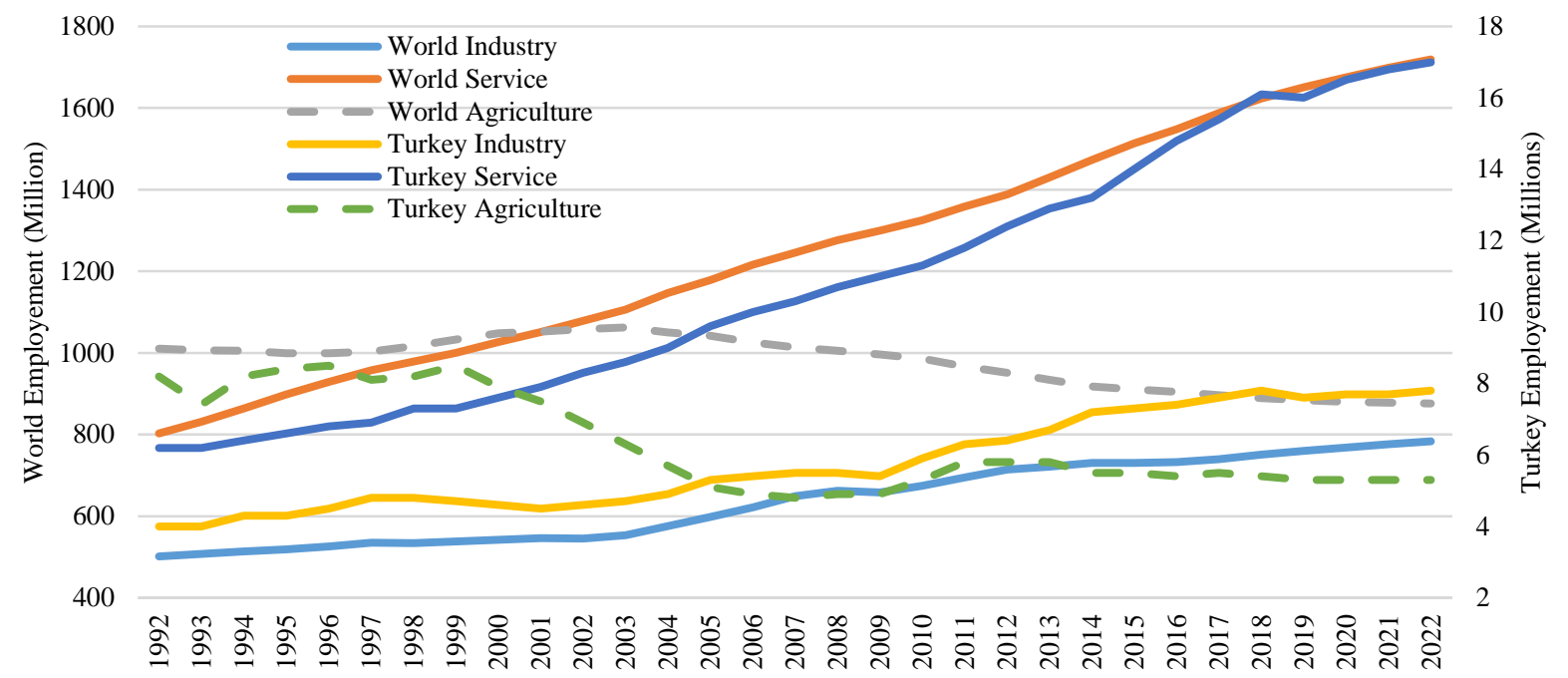

Figure 1. Change in the labor force on a sectoral basis in the world and in Turkey over the years (Anonymous, 2011).

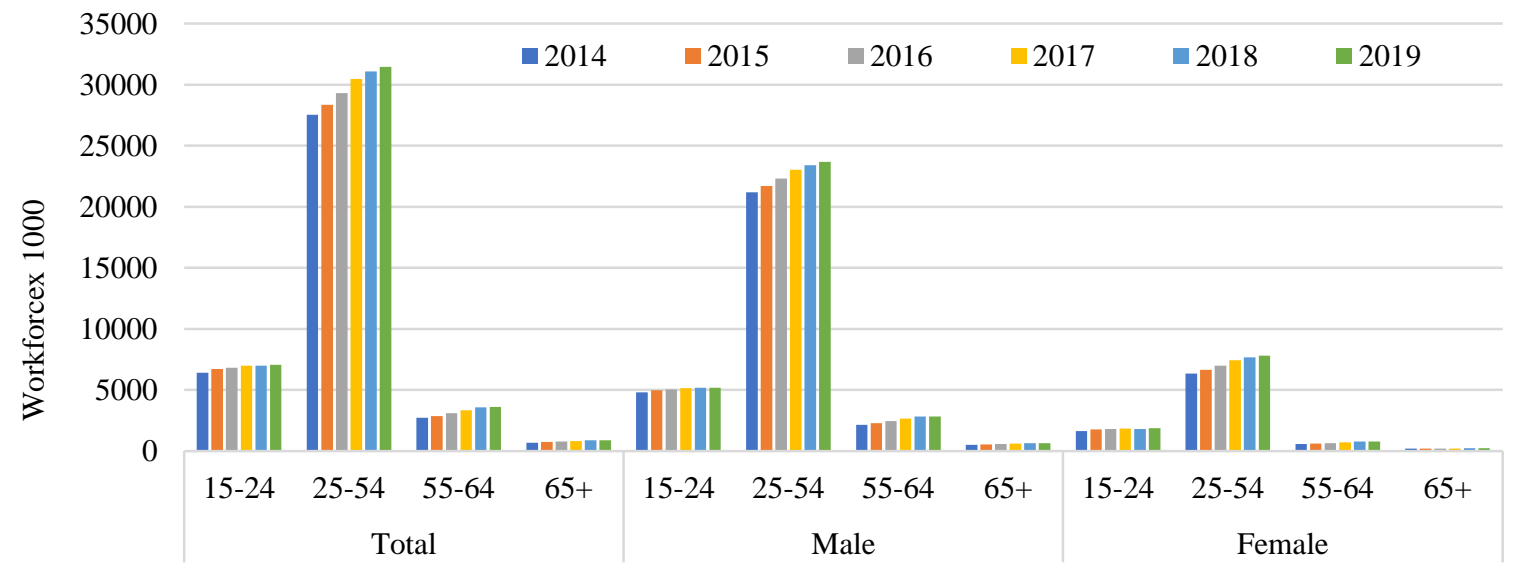

Figure 2. Distribution of total workforce and gender-age in Turkey between 2014-2019 (Anonymous, 2021j).

Turkey has an important workforce in terms of its general population and the proportion of young people in the population. While the number of people employed in agricultural production in Turkey was approximately 8.2 million in 1991, this number decreased to 5.3 million in 2020. While an increase was observed in the industry and service sectors, which are the other sectors where employment is provided, employment in the agricultural production sector decreased especially after 2003 (Anonymous, 2011).

The distribution of men and women aged 15 and over who joined the workforce between 2014-2019 in Turkey is given in Figure 2. According to 2019 data, while there are 43 million workforce in our country, 32.3 million (75.15\%) of this number are men and 10.7 million $(24.85 \%)$ are women. $73.17 \%$ of the workforce is comprised of those aged $25-54$.

\section{General Employment and Agricultural Employment} in Turkey

The distribution of employees in Turkey between the years $2014-2020$ by general reference work areas is given in Figure 3. The agricultural production sector ranks third in terms of employment in Turkey, with employment 
exceeding 5 million. Its rate in total employment is $17.71 \%$ in $2020.59 .71 \%$ of the employees employed in agricultural production activities are male and $40.29 \%$ are female. These numbers and rates consist of only recorded data and because unregistered employment is common in agricultural production, it can be said that the values will change in the direction of increase.

\section{Occupational Accidents and Occupational Diseases}

\section{in Turkey}

Every year, many workers in the world and in our country suffer from work accidents or get occupational diseases. Occupational accidents can result in non-fatal injuries or death. Temporary or permanent incapacity may occur because of occupational diseases.

The responsible institution for the evaluation of work accidents and occupational diseases in Turkey is the Social Security Institution (SSI). With the Social Insurance and General Health Insurance Law No. 5510, the State secures individuals; It specifies the persons who can benefit from these insurances and the rights to be provided to them, the conditions of benefiting, the financial coverage methods, and also regulates the procedures and principles regarding the operation of the insurance (Anonymous, 2021f).

Statistics on work accidents and occupational diseases are kept and published by the SSI. In this study, SSI statistics were considered to examine the data on work accidents and occupational diseases in our country. Statistics cover the years $2010-2019$. According to the recorded statistics, a total of 422,463 work accidents were experienced in 2019 in all sectors where employment was realized in our country and 1088 occupational diseases were reported. 1147 of the occupational accidents resulted in death. It is observed that death did not occur because of occupational diseases. This can be explained as the fact that SSI records an occupational disease in the same year in case of death because of occupational disease. When the data on occupational accidents are evaluated in terms of gender, it is seen that the rate of men is $79.80 \%$ and that of women is $20.2 \%$. While the death rate because of work accidents is $98.17 \%$ for men, it is $1.83 \%$ for women (Anonymous, 20211).

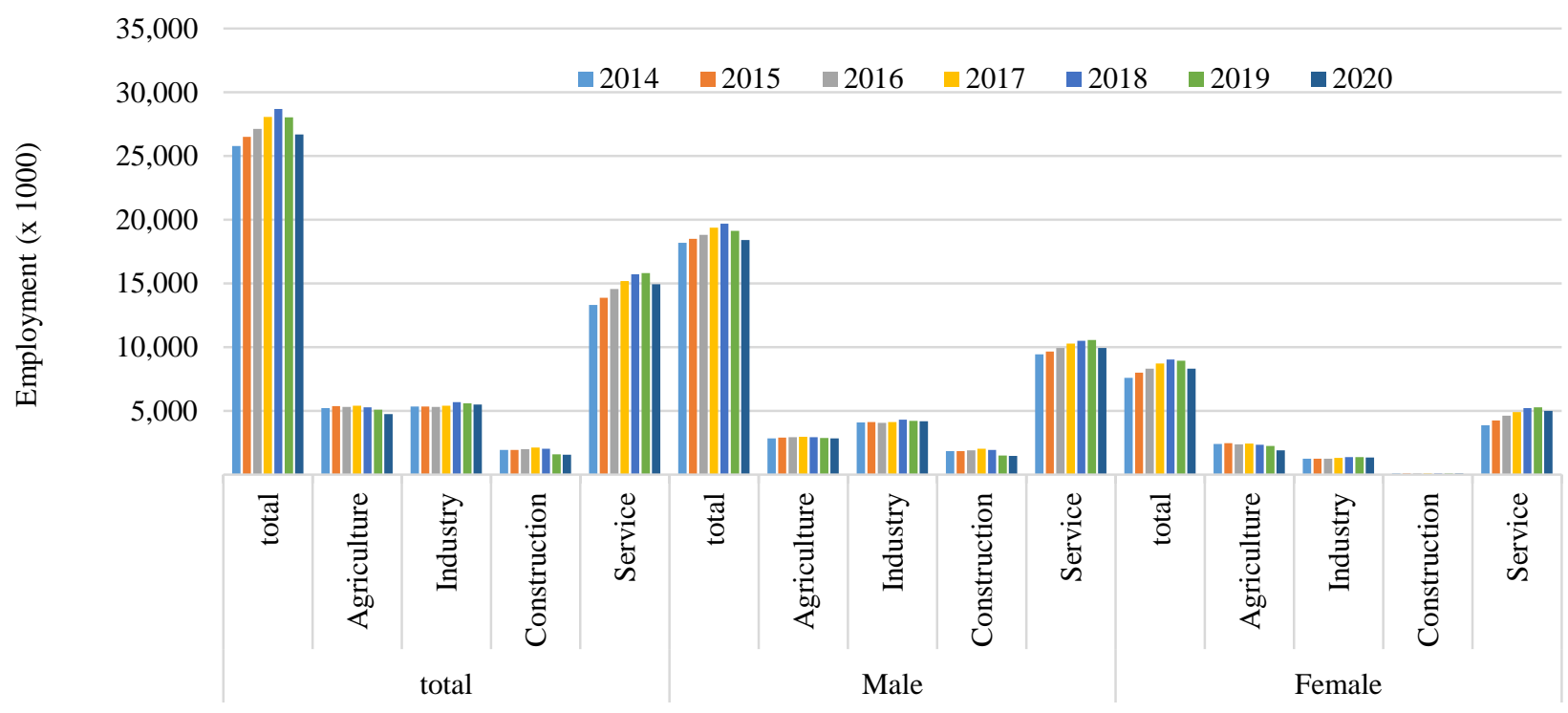

Figure 3. Distribution of total employment in Turkey between 2014-2020 by gender and reference sectors (Anonymous, 2021k)

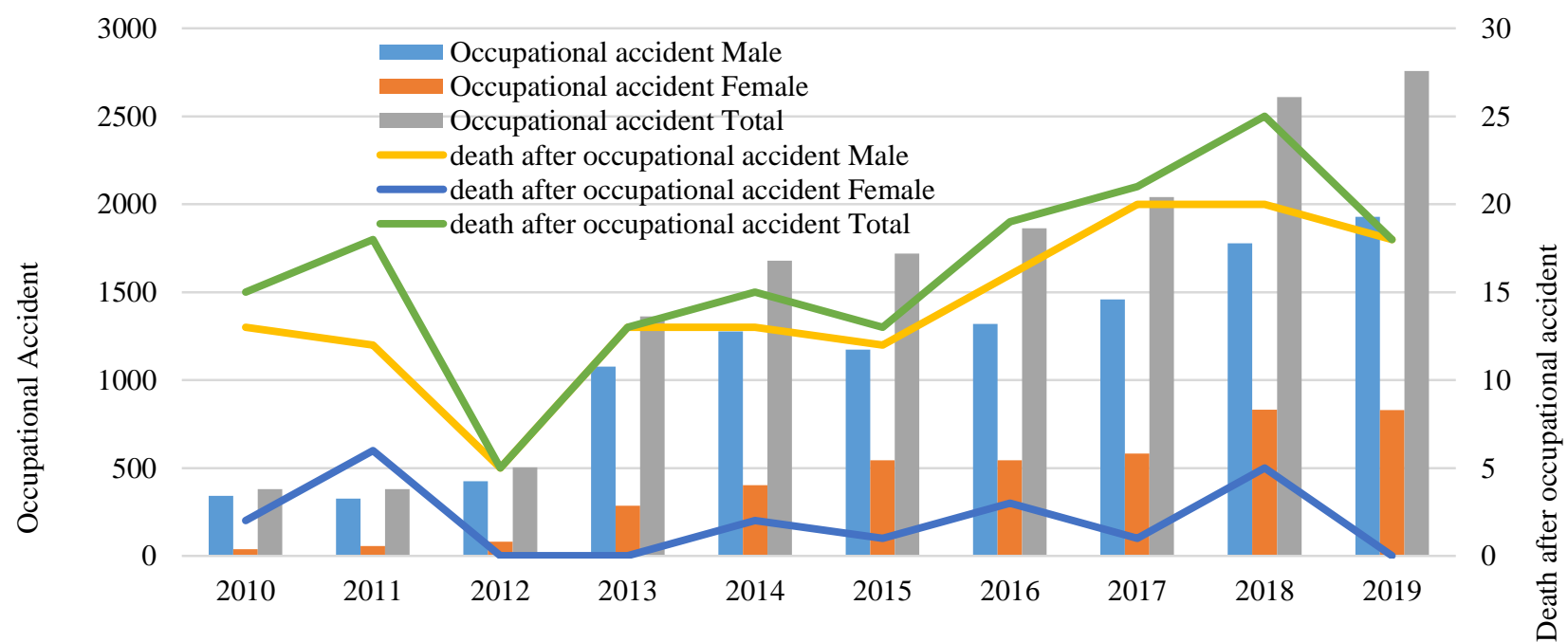

Figure 4. Distribution of agricultural production workers who had a work accident and died after a work accident in Turkey between 2010-2019 by gender (Anonymous, 20211). 


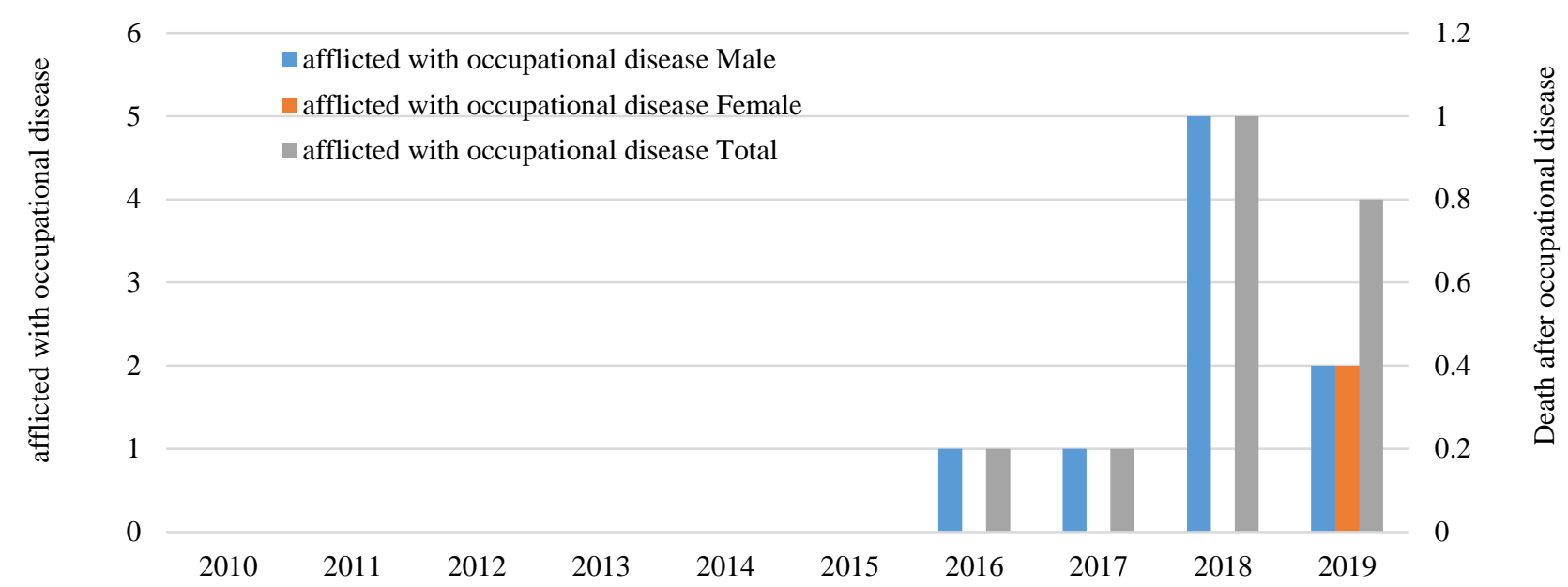

Figure 5. Distribution of agricultural production workers who suffered from occupational disease and died after occupational disease between 2010-2019 in Turkey by gender (Anonymous, 20211).

The data of agricultural production workers who lost their lives after having a work accident between 2010 and 2019 in our country are given in Figure 4. In 2019, a total of 2758 agricultural workers, 1929 men and 829 women, had occupational accidents, and 18 male employees lost their lives. When the data of previous years are examined, it is seen that the number of occupational accidents is increasing. The data of the agricultural production sector workers who were diagnosed with occupational diseases in our country between the years 2010-2019 are given in Figure 5. No occupational disease was observed between 2010 and 2015. Until 2018, all occupational diseases were seen in male employees. In 2019, an equal number of occupational diseases are encountered in women and men. Between 2010 and 2019, there was no death due to occupational disease among those working in the agricultural production sector.

\section{Legal Regulations in Turkey}

There is no law or regulation in Turkey that will directly cover those working in agricultural production. Social Security and General Health Insurance Law No. 5510 and Labor Law No. 4857 partially cover those working in agricultural production (Anonymous, 2021e; Anonymous, 2021f). Labor Law No. 4857, Article 4, subparagraph " $b$ " states that the provisions of the labor law will not be applied in "in the workplaces or enterprises where agricultural and forestry works are carried out with less than 50 workers (including 50)" (Anonymous, 2021e). On the other hand, the Occupational Health and Safety Law No. 6331 states that all businesses with 2 or more employees are within the scope of the relevant law. Intertwined sectors such as agriculture, forestry and aquaculture have also reached a level that can ensure employee safety. Occupational health and safety law numbered 6331 adopts proactive measures, that is, by determining the risks in advance, instead of a reactive approach, to prevent the accidents and occupational diseases that may occur or may occur. Even if the diversity and complexity of the hazard levels in agricultural production studies make this approach difficult, it is predicted that Occupational Health and Safety culture and awareness can be raised to sufficient levels because of a systemic and effective application. (Anonymous, 2021g).
Laws No. 6331 and 5510 have made it mandatory to report all occupational accidents suffered by insured employees to the SSI and law enforcement agencies, and this responsibility has been imposed on the employer by the law. The notification of work accidents and occupational diseases must be made to the relevant places within 3 working days. However, agricultural workers who do not have compulsory or optional registration with SSI do not or cannot make these notifications due to various legal concerns and/or financial inadequacies. This situation unintentionally hinders usable and real information flow. However, even if there are some exceptions in nonagricultural sectors, tracking and recording of accidents and occupational diseases can be done more easily and effectively.

Article 6 of Law No. 5510 states who are not considered to be insured. According to this article, from those who work in agricultural or forestry works in discontinuous jobs with a service contract and who work independently in agriculture on their own behalf and on their own account; Those who are engaged in agricultural activities and who certify that the monthly average of the amount remaining after deducting the expenses related to this activity from their annual agricultural activity income is less than thirty times the lower limit of daily earnings subject to premium defined in Law No.5510 (Anonymous, 2021h). When the issue of occupational health and safety in agricultural production is examined, it is a fact that sufficient awareness level has not yet been formed both in our country and in other countries of the world. The reason/reasons for this are pretty much the same. The reasons for this can be counted as, the lack of a common decision-making mechanism as a result of the fact that the majority of the workers in agricultural production are unorganized or the organizations formed by the organized segment cannot work properly, the education level of the people working in the agricultural production sector is generally low, the number of female employees in employment rates is high, the number of seasonal workers among the employed people is high or the high rate of displacement of the workforce and the difficulties in collecting statistical data or the scarcity of data (Ahioğlu, 2009; Anonymous, 2015; Çamurcu and Seyhan, 2015; Gülçubuk, 2017; Taş, 2019; Temel and Öztekin, 2020). 


\section{Risk Factors in Agricultural Production}

The agricultural production sector falls into the "Very Dangerous" and "Dangerous" class in risk classifications. Employers, engineers, technical intermediates and workers who create employment in such a dangerous and difficult sector must be trained on some basic issues in order not to be exposed to occupational accidents and occupational diseases (Ahioğlu, 2009; Akpınar and Özyıldırım, 2016; Anonymous, 2011; Yiğit, 2018; Yurtlu et al., 2015).

The fact that most of the agricultural production is carried out in open areas causes people working in agricultural activities to be affected more by climatic conditions and environmental factors than other employees. Briefly, these factors can be counted as, variable air temperature, variable humidity, air flow, dust, precipitation, sun rays, etc. (Ahioğlu, 2009; Akpınar and Özyıldırım, 2016). For the employees to continue their physical and mental activities within the climatic conditions, they must work under appropriate 'thermal comfort' conditions. Thermal comfort conditions can be easily achieved in a closed environment and its effects cannot be noticed immediately, while its effects can be seen immediately in open areas (Anonymous, 2015; Taş, 2019).

The factors that pose a danger to worker health and work safety are very diverse. These factors in terms of agricultural production; It is possible to examine the factors arising from physical, chemical, biological, ergonomic and machine use under five main groups (Ahioğlu, 2009; Akpınar and Özyıldırım, 2016; Anonymous, 2015; Çamurcu and Seyhan, 2015; Selek, 2020; Sert and Nazlıŏlu, 2014; Taş, 2019; Yiğit, 2018).

\section{Physical Risk Factors}

Physical risk factors are the leading risk factors in terms of human health and occupational safety in agricultural production enterprises. These risk factors can be listed as extreme heat and/or cold, sun rays, noise, vibration, dusts and gases, and electricity (Selek, 2020; Sert and Nazlıŏlu, 2014).

The most important factor for workers to work efficiently is thermal comfort. For thermal comfort, it is necessary to provide the appropriate temperature and humidity ratio. Very low or very high temperature and humidity values create the phenomenon called heat stress (Babalık, 2018; Çamurcu and Seyhan, 2015; Koç et al., 2019; Taş, 2019). Especially in terms of agricultural production, where physical work is intense, this situation reduces the productivity of the workers and puts human health at risk. Working under conditions with extremely hot or extremely cold working ambient temperature and high humidity $(80 \%$ or higher) may prevent the mechanisms that regulate the current body temperature of the employee from working properly in unsuitable conditions, causing problems for the employee. Initially, this can lead to decreased sweating, dizziness and fainting, headaches, confusion, skin rashes, irritability, fatigue, and muscle cramps. Working under high temperature as well as working under low temperature causes some problems. Hypothermia may occur in operating conditions consisting of a combination of low temperature and high wind speed
( $>5 \mathrm{~m} / \mathrm{s}$ ) and/or humidity and precipitation (rain, sleet or snow) (Koç et al., 2019; Taş, 2019).

As a necessity of working in open areas, those working in agricultural production are fully or partially exposed to sunlight and therefore to ultraviolet (Ultraviolet-UV) rays. Ultraviolet rays can cause skin and eye diseases. Although skin damage is irreversible, repeated or intermittent and intense exposures cause skin cancer and early wrinkling in the skin and cataract formation in the eye. On sunny days in summer, ultraviolet radiation is more intense between 10:00 and 14:00. This time interval is the time that is worked intensively especially in open agricultural areas. This increases the exposure time of workers to these rays. Sunburn may occur in those who work in unprotected open areas (Ahioğlu, 2009; Akpınar and Özyıldırım, 2016; Anonymous, 2015; Taş, 2019).

The main source of noise-induced hearing loss in agricultural production is the machinery and equipment used. Tractors, electric or chainsaws, threshers, dryers, etc., used as power sources. There are many sources of noise. The best method for reducing noise from agricultural machinery is to prevent it at the source and to improve the design. If the improvements made in the design and prevention at the source are insufficient, it can be suggested that the employees use personal protective equipment and reduce the working time in a noisy environment as a last resort (Akpınar and Özyıldırım, 2016; Çamurcu and Seyhan, 2015; Güğercin and Baytorun, 2018; Selek, 2020; Taş, 2019; Yiğit, 2018).

Vibrations created by machines such as tractors, soil tillage machines, saws, harvesting and threshing machines, baling machines and lawn mowers can be transmitted to the whole body, depending on whether they are carried by hand or on the back. Prolonged exposure to vibration can cause severe pain, joint and nerve damage. Depending on the duration of exposure of the whole body of the worker to vibration, permanent disability may occur at the end of the exposure time, but temporarily for short periods. Therefore, the exposure time of the worker to vibration and the magnitude of the vibration are important (Akpinar and Özyıldırım, 2016; Altuntaş and Yıldırım; 2016; Demirel, 2014; Güğercin and Baytorun, 2018; Özkan and Dilay, 2020; Sert and Nazlıoğlu, 2014).

In agricultural production, straw, pulp, cereal husks, mold, fungus and bacterial residues, pesticide residues, animal hair and hair, and pollen can be counted as dust sources. Depending on the process applied in agricultural production where powder is made, it may occur during tillage, product care and fertilization, harvesting and threshing, product processing and product packaging. The high level of organic dust generated in the workplaces where agricultural production activities are carried out may pose an explosion hazard. As a result of explosions that may occur, fire may occur, and accidents that may result in injury or death may occur. According to the particle size (smaller than 100 microns) of the dust in the working environment, it is not kept in the respiratory system of the worker and may cause accumulation in the bronchi in the lungs. This can lead to acute or chronic lung diseases, chronic diseases such as asthma and acute allergic alveolitis called "farmer's lung" (Anonymous, 2015; Sert and Nazlıŏlu, 2014; Taş, 2019; Yurtlu et. al., 2015). 
Electrical energy used in agricultural production is the second most common energy source after tractor. Risks arising from electricity are one of the common accident types in agricultural production stages. Electric shocks are experienced because of both contact with electrical transmission lines and operations made with machines that use electrical energy as a power source. Electric shock can be defined as "injury or death of a person as a result of contact with an electrical source such that electric current passes through the body" (Çamurcu and Seyhan, 2015; Taş, 2019).

\section{Chemical Risk Factors}

All kinds of elements, compounds or mixtures that are naturally found or produced, that occur as waste during any process, or that occur accidentally are called "Chemical Substances" and can be generally examined under two subheadings as Organic and Inorganic. Chemical substances enter the human body in three different ways. These; respiration, skin absorption and digestion (Selek, 2020; Taş, 2019; Yiğit, 2018).

Pesticides can be said as the general name of chemicals with very high carcinogenic properties, which are used to protect plants from diseases and to fight pests (Anonymous, 2020). Although there are different control methods in agricultural production, the use of pesticides is mostly preferred in our country. Pesticides used in agricultural production are named as herbicides, fungicides, insecticides, molluscoid, larvicides, nematicides, pesticides, ovicides and rodenticides according to their areas of use and the organisms they fight (Akpınar and Özyıldırım, 2016; Anonymous, 2015; Sert and Nazlıoğlu, 2014; Temel and Öztekin, 2020).

In agricultural production, fertilizers are used to increase product yield if organic and inorganic materials taken from the soil by the plant are missing. The fertilizers used are usually solid and can be applied directly to the soil. In addition, chemical fertilizers in powder form are mixed with soil or watered from the root area of the plant during irrigation. Chemical fertilizers used in solid, powder or water-soluble form are chemicals that workers in agricultural production encounter during application. It can enter the body through the skin during the application or in the form of eating and drinking by mistake (Demirel, 2014; Temel and Öztekin, 2020).

\section{Biological Risk Factors}

Another of the risk factors that are important for human health and occupational safety in agricultural production enterprises is biological risk factors. These risk factors can be listed as zoonosis, injuries caused by pets and injuries caused by wild animals. Zoonosis is defined as diseases that man and animal can infect each other and are commonly shaped in individuals in both groups. Sick animals, contact with animal waste and drinking polluted water are ways of transmission of zoonotic diseases to workers. Diseases such as anthrax, brucella, campylobacter, cryptosporidium, leptospirosis, psittacosis, rabies, orf and ringworm can be given as examples of zoonoses that come from animals to humans (Akpinar and Özyıldırım, 2016; Çamurcu and Seyhan, 2015; Demirhan et al., 2016; Güğercin and Baytorun, 2018).
Injuries caused by pets involve risks posed by the obligation of employees to work closely with the animal. These risks arise because of kicking, biting, hitting a hard place, erroneous behavior of the employee, triggering behavior of the animal or standing in a blind spot. Since agricultural production is carried out predominantly in open areas, it is inevitable that there will be no interaction between some wild animals living in nature and those who work. These interactions often have negative consequences for humans because of the reactions of wild animals to protect their nests, offspring or themselves. Wild boars, snakes, spiders, scorpions, etc. can attack humans and cause serious injuries (Demirhan et al., 2016; Güğercin and Baytorun, 2018; Menteş Gürler et al., 2020; Anonymous, 2015).

\section{Ergonomic Risk Factors}

Adverse factors that may occur due to working in nonergonomic conditions in agricultural production can cause temporary and/or permanent musculoskeletal disorders, injuries or injuries. In addition, because agricultural production is mostly carried out in open areas, working under extreme cold or extremely hot conditions, and the labor-intensive machinery and equipment used increase the risk level of the discomforts that may be encountered. Activities in agricultural production usually consist of jobs that require outpatient work. These activities can be counted as lifting-putting, lifting-carrying-repositioning, and working in a squatting or kneeling position (Demirel, 2014; Demirhan et al., 2016; ILO, 2011; Koç et al., 2019; Sert and Nazlığlu, 2014; Yurtlu et al., 2015).

\section{Risk Factors Caused by the Usage of Agricultural Machinery}

Machines used in agricultural production; tractor as a power source, soil tillage machines, sowing and planting machines, maintenance and spraying machines, harvesting and threshing machines and transport and transmission machines. As it is known, the strength and dimensions of tractors used in agricultural production are much higher than manpower. In the machines that use the tractor as a power source, the power is above the human power. For this reason, many accidents occur due to faulty behaviors and inadequate precautions taken by people (Ahioğlu, 2009; Akpınar ve Özyıldırım, 2016; Çamurcu and Seyhan, 2015).

The dangers and risks posed by the machinery used in agricultural production are the group that is more common than other hazards and risks in agricultural production and causes the most incapacity and death after accidents. There are two main reasons for this (Güğercin and Baytorun, 2018; Kayhan et al., 2019; Özkan and Dilay, 2020; Sert and Nazlıoğlu, 2014).

The first reason is that agricultural machinery consists of moving elements that move very fast or operate at high rotational numbers. The second reason is that most of the parts of the tractor and the machines it drives are in open working condition. For these reasons, the dangerous movements and situations of the employees accelerate the occurrence of accidents, and the number of accidents increases. The main sources of danger in tools and machines used in agricultural production can be listed as cutting parts, gear pairs, belt-pulley arrangements, shafts, 
other moving parts, hydraulic system leakage or electric shock (Altuntaş and Yıldırım; 2016; Anonymous, 2015; Demirel, 2014; Taş, 2019).

\section{Diseases Occurring in Agricultural Production}

Those who work in agricultural production face many diseases because of various risk factors in the environment. While it is possible to eliminate certain diseases by providing simple hygiene conditions, it is not possible to eliminate the factors of some diseases. For this reason, employer should provide the necessary training against the risk factors faced by employees and take the necessary measures to prevent risk factors (Taş, 2019; Yurtlu et al., 2015).

Diseases that occur in agricultural production vary depending on the physical condition of working people, working environments and time. Diseases seen in agricultural production; respiratory system diseases, musculoskeletal diseases, infectious diseases, reproductive health diseases, dermatological diseases, psycho-social diseases, cancer, accidents and injuries (Demirhan et al., 2016; Güğercin and Baytorun, 2018; Menteş Gürler et al., 2020; Sert and Nazlıŏglu, 2014).

\section{Measures to be Taken for Occupational Health and Safety in Agricultural Production}

During agricultural production, agricultural workers are exposed to many physical risk factors. At the beginning of these risk factors are the risks arising from the use of agricultural machinery that cause accident-injury and even death.

On the other hand, to reduce unhealthy and uncomfortable working conditions, ambient temperature, humidity, etc. Appropriate air-conditioning environment and ventilation practices should be provided to improve the conditions. The employer should provide clean drinking water to the employees and, if necessary, electrolyte supplementation and the amount excreted because of sweating should be provided. Water drinking places should be created at regular intervals in the working area within the existing possibilities. To prevent harmful and inappropriate working conditions caused by the sun's ultraviolet rays, employees should wear hats and glasses, prefer long-sleeved clothes, and use sunscreens with high protection factor. Workers should be rotated to reduce exposure time.

To prevent the ambient noise from harming the employees, the noise source should be identified, procedures should be applied to reduce the noise and if possible, it should be replaced with a noiseless or less noisy one. If these processes do not produce results, employees should be provided with personal protective equipment. In addition, the audiometric screening tests of the employees should be repeated at certain intervals, recorded and appropriate measures should be taken in case of possible changes.

Another negative situation for employees is the direct effect of the skeletal and muscular system. Vibration value, which is an important physical risk factor that causes harm to employees, must not exceed the limits specified in the legislation. The source of vibration should be determined, and engineering solutions should be applied to eliminate the working imbalance. If all the measures taken are insufficient, the employee should be ensured to use appropriate personal protective equipment.

It is important to carry out a risk assessment to protect agricultural workers from the harmful effects of dust and gases. Appropriate measurements should be made to determine the density of dust and gas in the environment, and necessary precautions should be taken to prevent dust and gas formation. Appropriate personal protective equipment should be used to protect workers from the harmful effects of dust and gases.

Pesticides and chemical fertilizers used in production are the biggest risk factors due to the use of chemicals for those working in agricultural production processes and those living in the environment. Business owners should evaluate the potential risks by examining pesticides and chemicals used in production, and then take measures to reduce or prevent employee exposure. Measures to be taken should be supported by engineering practices as well as by substitution method using non-hazardous or less hazardous chemicals.

Agricultural production can be divided into vegetable and animal production. The areas where crop production is made may also include the habitats of domestic or wild animals. The greatest precaution that workers or people working here can take against biological risk factors is education. It is necessary to explain what the risk factors are, what can be encountered because of exposure, and the methods of protection through regular trainings to be given to the employees. It is important that workers learn about animal behavior and know the methods to be used to approach animals. Environments where animals live should be illuminated at an appropriate level for employees. Employees should be aware of the emergency response methods to be applied to the exposed person in cases of possible injuries or poisoning. It should be ensured that appropriate clothing is worn to protect against these risks and that personal protective equipment is used when necessary.

Most agricultural production activities are laborintensive activities. Although mechanization has reached the desired level, the need for manpower is not over. For this reason, ergonomic incompatibilities such as musculoskeletal disorders that may be encountered in agricultural production, lifting and carrying heavy and shapeless loads, repetitive movements, and difficulties in using machines should be eliminated.

The employer must carry out a risk assessment to eliminate the ergonomic risks identified during work, and to take and supervise measures that reduce musculoskeletal injuries and diseases. As a result of the risk assessment, employers should first eliminate the danger and have their employees do work with non-hazardous or less dangerous methods. It should make the necessary maintenance and repairs of ergonomically dangerous machines and equipment, reduce the exposure times of employees with adequate rest periods and job changes if necessary, and protect them with suitable personal protective equipment as a last resort.

The machines used in agricultural production are generally so powerful that people cannot free themselves from the machine by their own power. Physical risks that 
may occur during the use of these machines, jamming, wrapping, cutting, impact, pulling, freely rotating parts and thrown/ejected objects. In order not to encounter such risks, employees must be at safe working distances. In addition, employers should provide adequate training to their employees about the risks of machinery. Machines must be equipped with appropriate protective equipment. During the repair and maintenance activities to be carried out for the malfunctions in the machines, it should be ensured that the machines are completely stopped, and it is very important to take the necessary measures to prevent the machine from working during the intervention.

\section{Conclusion and Recommendations}

It is important to protect the declining employment in the agricultural production sector, whose importance is increasing day by day in Turkey and in the world, against work accidents and occupational diseases. The agricultural production sector is one of the leading sectors in our country, with the number of employment exceeding 5 million in 2020 and its rate of $17.71 \%$ in total employment. $59.71 \%$ of the employees employed in agricultural production activities are male and $40.29 \%$ are female. In 2019, 2758 agricultural workers (74,82\% male, 25,18\% female) had occupational accidents and 18 male employees lost their lives. When the data of previous years are examined, it is seen that the number of occupational accidents is increasing. It would not be wrong to state that there are very serious deficiencies in the occupational safety situation in agricultural production in Turkey when compared to the developed countries. The number of studies in this field is few but commendable. The main reason why the studies on this subject are few and cannot be larger than the local or regional scale is that data collection is difficult and insufficient. The best solution to solve this problem is to determine a policy at the national level and to establish a well-functioning database or system.

The fact that most of the enterprises that carry out agricultural production activities in Turkey are in the form of family businesses, poses a second problem in terms of Occupational Health and Safety. In addition, it is not obligatory to apply the laws applied in our country in this type of family businesses with a low number of employees. The exceptional situation in the law emerges as the third factor leading to an increase in risks in terms of Occupational Health and Safety. When the profiles of the employed employees are examined, the low level of education, the habits and beliefs of the employees and the fact that they are familiar with the information they have learned from previous generations constitute an important obstacle to the spread of occupational health and safety practices. The effective implementation of Occupational Health and Safety practices by employers and employees and the fact that everyone has the OHS culture to be formed should be one of the biggest goals to be achieved for our country. The number of occupational accidents will gradually decrease with every measure to be taken to reach this goal. This will enable employees to carry out their work in a healthy and safe manner and will reduce the loss of workforce suffered by employers. The gains that will be added to the country's economy can be increased with the increased use of labor and productivity.

\section{Acknowledgment}

This article was presented as an oral presentation in II. International Turkish Journal of Agriculture - Food Science and Technology Congress (TURJAF 2021).

\section{Authors' Contributions}

Yaşar Serhat Saygllı: Validation, Writing - original draft, Review and editing, Methodology, Investigation, Conceptualization, Visualization.

Bülent Çakmak: Formal analysis, Data curation, Review and editing.

\section{Conflict of Interest}

The authors declare that they have no conflict of interest.

\section{References}

Ahioğlu SS. 2009. Tarımda İş Sağlığ1 ve Güvenliği. İş Sağlığı ve Güvenliği Dergisi, 41: 10-15.

Akpınar T, Özyıldırım K. 2016. Trakya Bölgesi'nde Tarımsal Faaliyette Bulunan Çiftçilerin İş̧ Sağlığı ve Güvenliği Açısından Değerlendirilmesi. Çalışma ve Toplum, 3: 1231$1270 \mathrm{~s}$.

Akyıldız S, Çakmak B, Alayunt FN, Karakitapoğlu NA. 2017.Tarım Sektöründe İş Sağlığı ve Güvenliği Kültürünün Geliştirilmesinde Medyanın Etkisi. Mühendislik Bilimleri ve Tasarım Dergisi, 5 (ÖS: Ergonomi2016): 257-261 s. DOI: 10.21923/jesd.37308

Altuntaş E, Yıldırım C. 2016. Tokat iline ait ilçelerde gerçekleşen traktör ve tarım makinaları iş kazalarının incelenmesi. Mediterr Agric Sci, 29(3): 117-124 s.

Anonymous, 2011. Safety and health in agriculture. ILO code of practice. International Labor Office - Geneva: ILO, 2011. ISBN 978-92-2-124970-2 (print) ISBN 978-92-2-124971-9 (Accessed 19.01.2021)

Anonymous, 2015. Tarımda İş Sağlığı ve Güvenliği Çalıştayı. Şanlıurfa. ISBN: 978-975-7113-53-9. http://web.harran.edu.tr/ assets/uploads/other/files/tarimda_is_sagligi/rapor.pdf (Accessed 11.03.2021)

Anonymous, 2020. Available from: https://www.isguvenligi.net/ yararli-bilgiler/pestisitlerin-saglik-etkileri/_ (Accessed 11.07.2020)

Anonymous, 2021a. Available from: https:/www.ilo.org/wcmsp5/ groups/public/---dgreports/---dcomm/---publ/documents/ publication/wcms_670542.pdf (Accessed 11.03.2021)

Anonymous, 2021b. Available from: https://www.ilo.org/ wcmsp5/groups/public/---dgreports/---dcomm/--publ/documents/publication/wcms_734455.pdf (Accessed 11.03.2021)

Anonymous, 2021c. Available from: https://www.ilo.org/ moscow/areas-of-work/occupational-safety-and health/WCMS_249278/lang--en/index.htm\#: :text=The\% 20ILO $\% 20$ estimates\%20that $\% 20$ some,of\% 20 work $\% 2$ Drelat ed\%20illnesses\%20annually (Accessed 11.03.2021)

Anonymous, 2021d. Available from: https://ilostat.ilo.org/ topics/employment/ (Accessed 11.03.2021)

Anonymous, 2021e. Türkiye Cumhuriyeti Cumhurbaşkanlığ Mevzuat Bilgi Sistemi. Available from: https://www.mevzuat.gov.tr/mevzuat?MevzuatNo=4857\&M evzuatTur $=1 \&$ MevzuatTertip=5 (Accessed 11.03.2021) 
Anonymous, 2021f. Türkiye Cumhuriyeti Cumhurbaşkanlığ Mevzuat Bilgi Sistemi. https://www.mevzuat.gov.tr/ mevzuat?MevzuatNo=5510\&MevzuatTur $=1 \&$ MevzuatTerti $\mathrm{p}=5$ (Accessed 11.03.2021)

Anonymous, 2021g. Türkiye Cumhuriyeti Cumhurbaşkanlığı Mevzuat Bilgi Sistemi. Available from: https://www.mevzuat.gov.tr/mevzuat?MevzuatNo=6331\&M evzuatTur $=1 \&$ MevzuatTertip $=5$ (Accessed 11.03.2021)

Anonymous, 2021h. Türkiye Cumhuriyeti Cumhurbaşkanlığ Mevzuat Bilgi Sistemi. Available from: https://www.mevzuat.gov.tr/mevzuat?MevzuatNo=18581\& MevzuatTur=7\&MevzuatTertip=5 (Accessed 11.03.2021)

Anonymous, 2021j. Türkiye İstatistik Kurumu. Available from: https://biruni.tuik.gov.tr/medas $/$ kn=92\&locale $=\operatorname{tr}($ Accessed 11.03.2021)

Anonymous, 2021k. Türkiye İstatistik Kurumu. Available from: https://data.tuik.gov.tr/Kategori/GetKategori?p=Istihdam,Issizlik-ve-Ucret-108 (Accessed 11.03.2021)

Anonymous, 20211. Sosyal Sigortalar Kurumu. Available from: http://www.sgk.gov.tr/wps/portal/sgk/tr/kurumsal/istatistik (Accessed 11.03.2021) Babalık FC. 2018. Mühendisler için Ergonomi İşbilim (altıncı baskı). DORA Basım-Yayın Dağıtım Ltd. Şti., ISBN: 978- 605-247-019-0

Bilir N. 2016. İş sağlığı ve güvenliği profili: Türkiye; Uluslararası Çalışma Örgütü, ILO Türkiye Ofisi - Ankara: ILO, 2016 ISBN: 9789228310627 ; 9789228310634 (web pdf) İş Sağlı̆̆ ve Güvenliği Profili, Türkiye. Available from: https://aybu.edu.tr/isg/contents/files/wcms_498818.pdf (Accessed 19.01.2021)

Çamurcu S, Seyhan TG. 2015. Tarım Sektöründe İş Sağlığı ve Güvenliği. Süleyman Demirel Üniversitesi Mühendislik Bilimleri ve Tasarım Dergisi, 3(3), ÖS: Ergonomi2015: 549$552 \mathrm{~s}$.

Demirel H. 2014. Tarımda İş Sağlığı ve Güvenliği. ÇSGB Çalışma Dünyası Dergisi, Cilt:2 Sayı:1: 88-104 s.

Demirhan SA, Çelen B, Çelen MF, Şahinler N. 2016. Hayvancılıkta İş Sağlığı ve Güvenliği. Nevşehir Bilim ve Teknoloji Dergisi, TARGID Özel Sayıs1: 303-314.

Güğercin Ö, Baytorun AN. 2018. Tarımda İş Kazaları ve Gerekli Önlemler. Çukurova Tarım Gida Bil. Der., 33(2): 157-168.
Gülçubuk B. 2017. 6331 Sayılı Tarımda İş Sağlığı ve Güvenliği Kanunu tarımda çalışanlar için bir şey ifade eder mi?. International Journal of Social Sciences and Education Research, 3(2): 573-582.

Kayhan İE, Baran MF, Öztekin YB. 2019. Tarım Makinelerinin Kullanımında Meydana Gelen İs Kazalarının Tespiti ve Değerlendirilmesi (Kırklareli İli Örneği). Tarım Makinaları Bilimi Dergisi, 15(1):19-33.

Koç S, Güler A, Akınbingöl AG, Çevik EE. 2019. Tarımda Ergonomik Riskler. T.C. Aile, Çalışma ve Sosyal Hizmetler Bakanlığı İş Sağlığı ve Güvenliği Genel Müdürlüğü, Ankara, 5-15.

Menteş Gürler A, Sanal Ş, Aslım G. 2020. Assessment of regulations on occupational health and safety in agriculture in Turkey from the point of livestock raising and veterinary medicine. Kafkas Univ Vet Fak Derg, 26 (2): 187-192. DOI: 10.9775/kvfd.2019.22680.

Özkan A, Dilay Y. 2020. Karaman İlinde Tarımsal Üretimde Traktör ve Tarım Makineleri Kaynaklı Kazaların Değerlendirilmesi. Tarım Makinaları Bilimi Dergisi, 16(1), 32-39.

Selek HS. 2020. İş Sağlığı ve Güvenliği (İSG) Temel Konular (Dördüncü Baskı). Seçkin Yayıncılık San. ve Tic. A.Ş. ISBN: 978-975-02-5984-5

Sert Ö, Nazlıŏlu A. 2014. Tarımda İş Sağlığı ve Güvenliği Rehberi. ÇSGB İş Sağlığı ve Güvenliği Genel Müdürlüğü Yayın No:44: 12-117.

Taş B. 2019. Tarımda İş Sağlığı ve Güvenliği. (İkinci Bask1). DORA Basım-Yayın Dağıtım Ltd. Şti. ISBN: 978-605-247095-4.

Temel U, Öztekin YB. 2020. Bitki Koruma Makinelerinin Kullanımının Tarımda İş Güvenliği Açısından Değerlendirilmesi. Anadolu Tarım Bilimleri Dergisi, 35: 6776. doi: 10.7161/ omuanajas. 627038

Yiğit, A. 2018. İş Güvenliği (Beşinci Baskı). DORA BasımYayın Dağıtım Ltd. Şti. ISBN:978-605-247-039-8, 157-212.

Yurtlu BY, Öz E, Alayunt FN, Çakmak B, Şimşek Z. 2015. Tarımda İş Sağlığ 1 ve Güvenliği. Türkiye Ziraat Mühendisliği

VIII. Teknik Kongresi, Ankara, 12-16 Ocak 2015. Cilt 2: 1435$1454 \mathrm{~s}$. 